\title{
IN VITRO ANTIBACTERIAL ACTIVITY OF ETHANOLIC EXTRACT OF SEEDPOD AND QUERCETIN OF NELUMBO NUCIFERA GAERTN
}

\begin{abstract}
RUVANTHIKA PN ${ }^{1}$, MANIKANDAN $\mathrm{S}^{2 *}$
${ }^{1}$ Department of Physiology, Tagore Medical College and Hospitals, Chennai - 600127 (PhD program in Bharath University, Chennai, 600073, India) Affiliated to TN Dr. MGR Medical University, Guindy, Chennai - 600 032, Tamil Nadu, India. ${ }^{2}$ Department of Physiology, Tagore Medical College and Hospitals, Affiliated to TN Dr. MGR Medical University, Guindy, Chennai - 600 032, Tamil Nadu, India.
\end{abstract}

Received: 04 August 2018, Revised and Accepted: 10 September 2018

ABSTRACT

Objective: The objective of the study was to evaluate whether ethanolic extracts of Nelumbo nucifera (EENN) seedpod and quercetin (active component of NN) possess antibacterial proprieties against Gram (-) bacteria such as Escherichia coli and Pseudomonas aeruginosa and Gram (+) bacteria such as Staphylococcus aureus.

Methods: Antibacterial activities of EENN seedpod and quercetin were investigated using disc diffusion method, minimum inhibitory concentration against E. coli and P. aeruginosa and Gram (+) bacteria such as S. aureus.

Results: The antibacterial activity of both EENN seedpod and quercetin was found to be increased in dose-dependent manner. The maximum zone of inhibition was exhibited by both EENN seedpod and quercetin against E. coli (14 mm and $15 \mathrm{~mm})$ and P. aeruginosa $(13 \mathrm{~mm}$ and $15 \mathrm{~mm})$. Gramnegative bacteria were more susceptible to the EENN seedpod extract and quercetin than Gram-positive bacteria.

Conclusion: The results of the present study suggested that the effect of EENN seedpod and quercetin against the tested bacteria in vitro may contribute to the in vivo activities of the EENN seedpod and quercetin.

Keywords: Nelumbo nucifera, Escherichia coli, Staphylococcus aureus, Pseudomonas aeruginosa.

(c) 2019 The Authors. Published by Innovare Academic Sciences Pvt Ltd. This is an open access article under the CC BY license (http://creativecommons. org/licenses/by/4. 0/) DOI: http://dx.doi.org/10.22159/ajpcr.2019.v12i1.28915

\section{INTRODUCTION}

In ancient time, plant extracts have been used in traditional medical systems for the treatment of microbial diseases [1]. Drugs used in modern medical system have become less efficient because of the development of resistance in pathogenic microorganisms, and hence, new antimicrobial drug discoveries have become essential [2]. Antimicrobial activities of phytochemicals in various plant extracts were investigated and provide the source for the natural antimicrobial drugs [3]. In recent times, search for compounds with antimicrobial activity has gained increasing importance, due to alarming increase in the rate of infection by antibioticresistance microorganisms [4]. In earlier studies, it has been shown that therapeutic potential of plant origin is not associated with side effects contrary to the synthetic drugs $[5,6]$. Therefore, researches on drugs against microbial infections are increasingly turning their attention to folk medicine [7].

Nelumbo nucifera (NN) is a perennial, aquatic crop that is used throughout Asia and cultivated for its edible rhizomes, stems, seeds, and leaves. All parts of NN are shown to contain number of secondary metabolites such as alkaloids, flavonoids, steroids, triterpenoids, glycosides, and polyphenols [8]. Some of the plants have different constitutions and concentrations, thus have an activating or inhibiting effect on microbial growth $[9,10]$. Phenolics are widely distributed in plants, are a class of plant secondary metabolites that contain one or more hydroxyl derivatives of benzene rings, and may affect the growth and metabolism of bacteria and used for defensive functions in many plants [11,12]. In many parts of the world, lotus is utilized as herbal medicine for the treatment of many diseases including heart problems, hypertension, diarrhea, insomnia, and cancer $[13,14]$. Various parts of lotus plant such as buds, flowers, anthers, stamens, fruits, leaves, stalks, rhizomes, and roots were used in traditional medicine $[15,16]$. Lotus was studied for its pharmacological properties such as antipyretic, antiviral, antidiarrheal, anti-inflammatory immunomodulatory, hypoglycemic, antioxidant, psychopharmacological, lipolytic, anticancer, and hepatoprotective activities [17]. In literature review, it was found that the seedpod of NN (white lotus) had not been screened for antibacterial properties so far. From this viewpoint, this study was carried out to evaluate the antibacterial activity of EENN white seedpod and its active component quercetin.

\section{METHODS}

\section{Procedure}

Collection, identification, and extraction of plant material NN seedpod was collected from a pond near Avadi, Chennai, Tamil Nadu, India. The plant material was authenticated and a voucher specimen was deposited in the herbarium in National Institute of Siddha, Tambaram, Chennai (No: NISMB1442014). The plant materials were cleaned, dried in shade, and grinded to fine powder with the help of a mixer grinder, and ethanolic extract was prepared using $90 \%$ ethanol by Soxhlet apparatus and extract was stored at $4^{\circ} \mathrm{C}$ until use.

\section{Identification of bacterial strains}

Staphylococcus aureus, Escherichia coli, and Pseudomonas aeruginosa pure isolates used in this study were obtained from Hi-Media Laboratories. All samples were cultured and subcultured again for purity on Blood Agar plates. Colony morphology and Gram staining were done to confirm the identity of working strains.

\section{Preparation of extract dilutions}

A stock solution of the plant extract was made by dissolving $100 \mathrm{mg}$ of extract in $10 \%$ dimethyl sulfoxide and then diluted using sterile Mueller-Hinton broth. Therefore, the initial concentration of the plant extract was $(100 \mathrm{mg} / \mathrm{mL})$. The above process was repeated several times to obtain other dilutions: $100,50,25$, and $10 \mu \mathrm{g} / \mathrm{mL}$. 


\section{Inoculation procedure}

The bacterial inoculum was prepared with Mueller-Hinton broth which was similar to the disc, then incubated at $37^{\circ} \mathrm{C}$ for $18-24 \mathrm{~h}$, and the bacterial concentration was adjusted to a $0.5\left(1.5 \times 10^{8} \mathrm{CFU} / \mathrm{mL}\right)$. Sterile broth and the suspension were diluted in the ratio of 1:100 to obtain a cell number of approximately $10^{6} \mathrm{CFU} / \mathrm{mL}$. To the tubes containing $0.5 \mathrm{~mL}$ of diluted extracts, $0.5 \mathrm{~mL}$ of the standardized bacterial suspension was added to produce a final cell count of about $5 \times 10^{5}$ $\mathrm{CFU} / \mathrm{mL}$. A tube containing broth, extract solvent either distilled water or $10 \%(\mathrm{v} / \mathrm{v})$ Tween-20, and the inoculums were known as positive growth controls [18]. The negative control was a tube containing broth without inoculum, and extract solvent which was incubated overnight at $37^{\circ} \mathrm{C}$.

\section{Antimicrobial susceptibility testing \\ Disc diffusion test}

Disc diffusion method for antimicrobial susceptibility testing was carried out based on recommendations given by the Clinical Laboratory Standards Institute, 2007 [18].

\section{Preparation of impregnated discs}

To $100 \mathrm{mg}$ of extract, $1 \mathrm{~mL}$ of their respective solvents was added to prepare a stock solution of plant extract and impregnated in sterilized $6 \mathrm{~mm}$ blank discs. Distilled water and dimethyl sulfoxide-loaded discs were used as negative controls for methanolic extract respectively. All impregnated discs were fully dried in $45^{\circ} \mathrm{C}$ incubator for $18-24 \mathrm{~h}$ before the application on bacteria. The standard antibiotic disc used as positive controls was vancomycin $(30 \mu \mathrm{g})$ for all strains.

\section{Application of impregnated discs}

The discs which were impregnated with plant extracts using sterile forceps were applied on the inoculated Mueller-Hinton agar once it has completely dried [19]. The discs were gently pressed to obtain uniform contact with agar surface. In each one of the test plates, three discs were placed in equidistance to each other to avoid the overlapping of inhibition zone. Three treated discs, one is treated with distilled water, one negative control, and the last one was treated with extract. The plates were then inverted and incubated for $24 \mathrm{~h}$ at $37^{\circ} \mathrm{C}$. The antibacterial activity assessment was measured with the diameter of inhibition zone around the treated discs and the control discs. If activity is present, their diameters were measured to the nearest whole millimeter with a ruler. All tests were done for three times to obtain reliability, and the average of the three replicates for each extract, and antibiotic was calculated.

Determination of minimum inhibitory concentration (MIC) values The lowest concentration of extract dilution with no visible growth was taken as MIC value. The tubes were then further incubated another $24 \mathrm{~h}$ and plated again to observe for presence or absence of growth after an incubation period of $48 \mathrm{~h}$ and at the same period of MIC value was recorded too.

\section{Statistical analysis}

Results for all the parameters analyzed were expressed as the mean \pm standard error of the mean. The statistical analysis of data was conducted with Statistical Package for the Social Sciences (SPSS) software (version 13.0; SPSS Inc., IL, USA) for Windows. Comparisons among groups that were more than two were performed using one-way analysis of variance (ANOVA) followed by Dunnett's $t$-test.

\section{RESULTS}

The antibacterial activity of the EENN seedpod extracts was evaluated at different concentrations $(10,25,50$, and $100 \mu \mathrm{g} / \mathrm{mL})$ against three bacterial strains by the disk diffusion method and the results are summarized in Table 1 . The antibacterial activity of both EENN seedpod extract and quercetin (Table 2) was found to be increased in dose-dependent manner. The maximum zone of inhibition was exhibited by both EENN seedpod and quercetin against E. coli (14 $\mathrm{mm}$ and $15 \mathrm{~mm}$ ) (Fig. 1) and P. aeruginosa (13 mm and $15 \mathrm{~mm}$ ). The moderate zone of inhibition was found in both EENN seedpod and quercetin against $S$. aureus (12 $\mathrm{mm}$ and $15 \mathrm{~mm}$ ). However, the results revealed that the EENN seedpod showed slightly lower antibacterial activity when compared to quercetin which shows the major activity of any drug is contributed by its quercetin which is a flavonoid, and these results were compared with the standard antibiotic vancomycin $(30 \mu \mathrm{g} / \mathrm{mL})$. It was observed from the result that antibacterial activity of the EENN increased with the increase in the concentration used. Statistical significance of the data demonstrated that concentration of extract at $10 \mu \mathrm{g}$ exhibited least significant $(\mathrm{p}<0.05), 25$ and $50 \mu \mathrm{g}$ exhibited moderate significant $(\mathrm{p}<0.01)$, and $100 \mu \mathrm{g}$ and standard showed highly significant $(\mathrm{p}<0.001)$ maximum zone of inhibition.

\section{DISCUSSION}

Recently, many medicinal plants are being studied for the presence of phytochemicals which include various classes of bioactive compounds such as alkaloids, flavonoids, and tannins, which has many pharmacological activities. Different parts of many plants such as root, stem, leaves, seeds, and flowers were reported for various biopharmacological activities such as antiviral, antibacterial, antifungal, antioxidant, and anti-inflammatory properties. Bacterial infection has become one of the most serious global health issues nowadays and requires natural remedy since drug-resistant microbes have become a serious issue. Lotus has been used both as food and medicine in Asia, particularly in India [20]. Gram-negative bacteria were more susceptible to the EENN seedpod and quercetin than Gram-positive bacteria which correlate with the previous reports done in NN flowers [21]. The results of this study revealed that the EENN seedpod showed slightly lower antibacterial activity

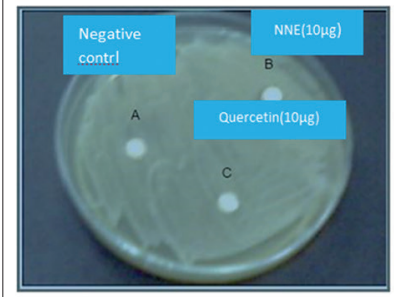

C-Quercitin $(10 \mu \mathrm{g})$

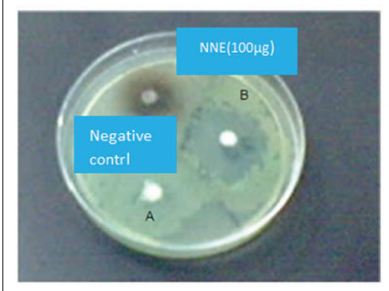

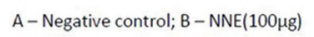

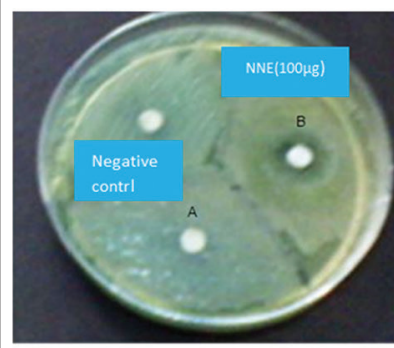

A- Negative control; B - NNE( 25 $\mu \mathrm{g})$
A-Negative control; B-NNE $(10 \mu \mathrm{g})$;

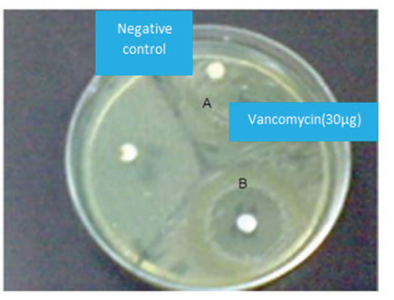

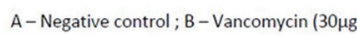

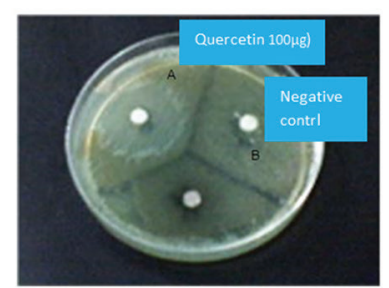

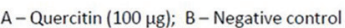

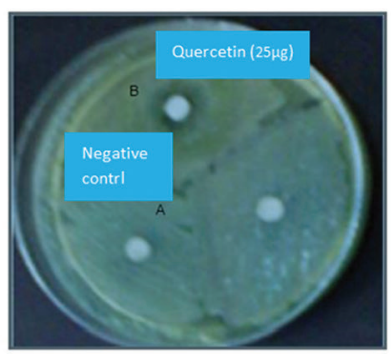

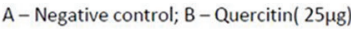

Fig. 1: Antibacterial activities shown by zones of inhibition by NNE and quercetin on Escherichia coli 
Table 1: Antibacterial activity of NN extract

\begin{tabular}{llll}
\hline Concentration $(\mu \mathrm{g} / \mathrm{mL})$ & \multicolumn{2}{l}{ Zone of inhibition $(\mathrm{mm})$} & \\
\cline { 2 - 4 } & Escherichia coli & Staphylococcus aureus & \multicolumn{1}{c}{ Pseudomonas aeruginosa } \\
\hline $10(\mathrm{~A})$ & $1.05 \pm 0.01^{*}$ & $1.06 \pm 0.01^{*}$ & $1.02 \pm 0.01^{*}$ \\
$25(\mathrm{~B})$ & $5.13 \pm 0.28^{* *}$ & $4.01 \pm 0.18^{* *}$ & $5.07 \pm 0.21^{* *}$ \\
50 (C) & $7.89 \pm 0.51^{* *}$ & $6.13 \pm 0.31^{* *}$ & $14.14 \pm 0.24^{* *}$ \\
$100(\mathrm{D})$ & $14.57 \pm 0.89^{* * *}$ & $12.42 \pm 0.95^{* * *}$ & $13.54 \pm 0.56^{* * *}$ \\
Positive control & $15.56 \pm 0.95^{* * *}$ & $13.69 \pm 0.84^{* * *}$ & $15.09 \pm 0.82^{* * *}$ \\
Negative control & $\mathrm{NI}$ & $\mathrm{NI}$ & $\mathrm{NI}$ \\
\hline
\end{tabular}

NI means no inhibition zone. Each value is expressed as mean \pm standard error of mean $(n=3) .{ }^{*} \mathrm{p}<0.05,{ }^{* *} \mathrm{p}<0.01$, and ${ }^{* * *} \mathrm{p}<0.001$ as compared with negative control.

N. nucifera: Nelumbo nucifera

Table 2: Antibacterial activity of quercetin

\begin{tabular}{llll}
\hline Concentration $(\mu \mathrm{g} / \mathrm{mL})$ & \multicolumn{2}{l}{ Zone of inhibition $(\mathrm{mm})$} & \\
\cline { 2 - 4 } & Escherichia coli & Staphylococcus aureus & \multicolumn{1}{c}{ Pseudomonas aeruginosa } \\
\hline $10(\mathrm{~A})$ & $1.04 \pm 0.56^{*}$ & $1.02 \pm 0.83^{*}$ & $1.06 \pm 0.95^{*}$ \\
$25(\mathrm{~B})$ & $5.41 \pm 0.21^{* *}$ & $4.23 \pm 0.17^{* *}$ & $5.13 \pm 0.11^{* *}$ \\
$50(\mathrm{C})$ & $7.91 \pm 0.21^{* *}$ & $7.13 \pm 0.19^{* *}$ & $7.05 \pm 0.23^{* *}$ \\
$100(\mathrm{D})$ & $15.64 \pm 0.12^{* * *}$ & $15.72 \pm 0.13^{* * *}$ & $15.58 \pm 0.14^{* * *}$ \\
Positive control & $15.14 \pm 0.10^{* * *}$ & $13.61 \pm 0.17^{* * *}$ & $15.05 \pm 0.19^{* * *}$ \\
Negative control & $\mathrm{NI}$ & $\mathrm{NI}$ & $\mathrm{NI}$ \\
\hline
\end{tabular}

NI means no inhibition zone. Each value is expressed mean \pm standard error of mean $(n=3) .{ }^{*} p<0.05,{ }^{* *} p<0.01$, and ${ }^{* * *} \mathrm{p}<0.001$ as compared with negative control

when compared to quercetin. It was suggested that the antimicrobial component in the plant that is bioactive compounds interacts with enzymes and proteins of the microbial cell membrane causing its disruption and causes the dispersal of flux of protons toward cell exterior which induces cell death or may inhibit enzymes necessary for amino acids biosynthesis $[22,23]$. The quercetin of NN seedpod is responsible for antibacterial activity. This supports usage of NN for treating fever and also in traditional medicine. In a previous study, it was shown that ethanolic extract of white NN flowers possessed strong antibacterial activity when compared to the pink flowers, this well correlated with our study similar strong antibacterial activity was evaluated in white NN seedpod also and more activity was attributed to quercetin which is a flavonoid the predominant component in many plant extracts [21].

\section{CONCLUSION}

The findings of this study confirmed the therapeutic potency of white lotus seedpod and quercetin used in traditional medicine. Hence, it can be concluded that the EENN possess a powerful antibacterial action against the organism which were tested which is due to quercetin. Herbal extracts have less toxicity compared to synthetic drugs and also reduce the side effects. Through this work, we have found that white lotus seedpod contains flavonoids quercetin which acts against microorganisms and forms a basis for natural source of antibacterial drug.

\section{ACKNOWLEDGMENTS}

We are thankful to the Dean, Tagore Medical College and Hospital, Chennai, for their encouragement to carry out this study and also Biogen Care Research Centre, Chennai - 600 014, for providing infrastructure facilities to conduct this work.

\section{AUTHORS' CONTRIBUTIONS}

P.N. Ruvanthika contributed for carry out experiment and computation of data. S. Manikandan contributed for data analysis and preparation of manuscript.

\section{CONFLICTS OF INTEREST}

The authors declare that they have no conflicts of interest.

\section{REFERENCES}

1. Akinmoladun AC, Ibukun EO, Afor E, Obuotor EM, Farombi EO. Phytochemical constituent and antioxidant activity of extract from the leaves of Ocimum gratissimum. Sci Res Essays 2007;2:163-6.

2. Nascimento GG, Locatelli J, Freitas PC, Silva GL. Antibacterial activity of plant extracts and phytochemicals on antibioticresistant bacteria. Brazil J Microbiol 2000;31:247-56.

3. Nair R, Chanda S. Activity of some medicinal plants against certain pathogenic bacterial strains. Indian J Pharm 2006;38:142-4.

4. Davis PH. Flora of Turkey and East Eagean Island. Edinburg: Edinburg University Press; 1982. p. 47.

5. Cowan MM. Plant products as antimicrobial agents. Clin Microbiol Rev 1999;12:564-82.

6. Kumaraswamy MV, Kavitha HU, Sathish S. Antibacterial evaluation and phytochemical analysis of Betula utilis against some human pathogenic bacteria. World J Agric Sci 2008;4:661-4.

7. Pitchai D, Manikkam R, Rajendran SR, Pichai G. Database on pharmacophore analysis of active principles from medicinal plants. Bioinformation 2010;5:43-5.

8. Mukherjee PK, Mukherjee D, Maji AK, Rai S, Heinrich M. The sacred lotus (Nelumbo nucifera) - Phytochemical and therapeutic profile. J Pharm Pharm 2009;61:407-22.

9. Vaquero MJ, Alberto MR, De Nadra MC. Antibacterial effect of phenolic compounds from different wines. Food Control 2007;18:93-101.

10. Moharram BA, Al-Mahbashi HM, Saif-Ali R, Ali Aqlan F. Phytochemical, anti-inflammatory, antioxidant, cytotoxic and antibacterial study of Capparis Cartilaginea Decnefrom yemen. Int J Pharm Pharm Sci 2018;10:38-44.

11. Nazemiyeh H, Rahman MM, Gibbons S, Nahar L, Delazar A, Ghahramani MA, et al. Assessment of the antibacterial activity of phenylethanoid glycosides from Phlomis lanceolata against multiple-drug-resistant strains of Staphylococcus aureus. J Nat Med 2008;62:91-5.

12. Shetty SG, Hidayathulla VS, Chandrashekar KR. Antimicrobial activity and phytochemical screening of Pterospermum reticulatum wight and arn. Review article. Int J Pharm Pharm Sci 2011;3:35-7.

13. Boudet AM. Evolution and current status of research in phenolic compounds. Phytochemistry 2007;68:2722-35.

14. Sridhar KR, Rajeev B. Lotus - A potential nutraceutical source. J Agricl Technol 2007;3:143-55.

15. Shen-Miller J, Schopf JW, Harbottle G, Cao RJ, Ouyang S, Zhou KS, et al. Long-living lotus: Germination and soil g-irradiation of centuriesold fruits, and cultivation, growth, and phenotypic abnormalities of offspring. Am J Botany 2002;89:236-47.

16. Duke JA, Bogenschutz-Godwin MJ, du Cellier J, Duke AK. Handbook of Medicinal Herbs. New York: CRC Press; 2002. 
17. Mehta NR, Patel EP, Patani PV, Shah B. A review on ethanobotany, phytochemistry and pharmacology. Indian J Pharm Biol Res 2013;1:152-67.

18. Jorgensen JH, Hindler JF. New consensus guidelines from the clinical and laboratory standards institute for antimicrobial susceptibility testing of infrequently isolated or fastidious bacteria. Clin Infect Dis 2006;44:280-6.

19. Zaidan MR, Noor Rain A, Badrul AR, Adlin A, Norazah A, Zakiah I, et al. In vitro screening of five local medicinal plants for antibacterial activity using disc diffusion method. Trop Biomed 2005;22:165-70.1.

20. Sumazian Y, Syahida A, Hakiman M, Maziah M. Antioxidant activities, flavonoids, ascorbic acid and phenolic contents of Malaysian vegetables. J Med Plants Res 2010;4:881-90.

21. Brindha D, Arthi D. Antimicrobial activity of white and pink Nelumbo nucifera gaertn flowers. Asian J Pharm Clin Res Health Care 2010;2:147-55.

22. Burt S. Essential oils: Their antibacterial properties and potential application in foods: A review. Int J Food Microbio 2004;94:223-53.

23. Gill AO, Holley RA. Disruption of Escherichia coli, Listeria monocytogenes and Lactobacillus sakei cellular membranes by plant oil aromatics. Int J Food Microbio 2006;108:1-9. 